\title{
Psyche and Society: Some Personal Reflections on the Development of the Cultural Complex Theory
}

\author{
Thomas Singer, M.D. \\ C.G. Jung Institute of San Francisco and Board of National ARAS \\ (The Archive for Research into Archetypal Symbolism)
}

\begin{abstract}
Beginning with a review of the current development of cultural complex theory, this article discusses the notions of the "collective psyche: "thin times", the cultural complex as being like a "teratoma" and the major characteristics of cultural complexes. The article is framed in terms of "personal reflections" of Thomas Singer who places the development of the ideas in the context of his personal development as a Jungian analyst. The theory and practice of "cultural complexes" is likened to a cultural circumambulation of highly conflicted political, social, economic and environmental issues in which the search for effective action is always at issue.
\end{abstract}

\begin{abstract}
Much of what tears us apart in the world today can be understood as the manifestation of autonomous processes in the collective and individual psyche that organize themselves as cultural or group complexes - which one can metaphorically imagine as accumulating in the collective psyche much like a newly reported area in the Pacific ocean where microscopic plastic particles from around the world seem to be coming together in a massive glob that fills an area the size of Texas. Cultural complexes are every bit as real, every bit as formative, every bit as ubiquitous, and every bit as powerful in their emotional and behavioral impact on individuals and groups as are personal complexes. Indeed, cultural complexes may present the most difficult and resistant psychological challenge we face in our individual and collective life today.
\end{abstract}

Thomas Singer, unpublished remarks to the Berlin Jung Society

\section{Introduction}

It has been a decade since Sam Kimbles and I co-edited The Cultural Complex (Singer \& Kimbles, 2004). It seems timely now to reflect on how the idea has evolved in my thinking. At times, my work on the cultural complex theory has felt like what happens with a "big dream." When you first have that dream and write it 


\section{Journal of Jungian Scholarly Studies 2}

down, you know it has something to say to you, but it often takes a long time to work out its multilayered meanings. That has certainly been true for me with the cultural complex theory-which I sometimes refer to as a theory, sometimes as a hypothesis, and sometimes as a notion. The important thing is that over time various aspects of the project have seemed deserving of more emphasis and/or clarification. In this paper, I would like to share some of the ongoing reflections that I have had as I have lived with the idea for the past decade, explored it with others, and entertained the questions/criticisms of others.

\section{The Collective Psyche}

My first exposure to Jung was in the 1960s when I was a medical student. His deep affirmation of the inner reality of the psyche was instantaneously recognizable and convincing to me. Not only did Jung's acknowledgement of the inner reality of the individual psyche speak to me, but also his feeling for the inner reality of the collective psyche, which I intuitively knew I was swimming in from my earliest years and which was bubbling over in American society with enormous energy by my mid-20s in the 1960s. Just as we have learned to recognize special geographic locations as being "thin places," locales where, as Eric Weiner (2012) writes, "the distance between heaven and earth collapses and we're able to catch glimpses of the divine, or the transcendent or, as I like to think of it, the Infinite Whatever" (para. 2), we might also designate certain eras in history as "thin times"-when the distance between the everyday and the collective unconscious collapses and we get glimpses of all sorts of extraordinary psychic realities - good and bad.

For me and many other Jungians who came of age in the later 1960s, that was a "thin time." Potent tribal impulses sprang to life in a generation that had spent its childhood in post-World War II prosperity and adherence to convention. By looking at the clothing and hair styles of the late $60 \mathrm{~s}$, one can tell that something was breaking through the conventionality of the 1950s. The most ordinary event suddenly became charged with the numinous energy of the archetypal. These were, indeed, "thin times."

Jung himself was sensitive to "thin times," as he unforgettably writes in his visions of the map of Europe being covered with blood before the outbreak of World War I (1963, p. 175). Thus, Jung's receptivity to the inner reality of the collective psyche much earlier in the 20th century spoke directly to my own inner experience in the late 1960s. As Jung and his psychology matured, a focus on "the collective psyche" became less prominent and those who followed in Jung's footsteps directed more and more of their attention, like Jung, to the individuation process. When I was growing up in the Jungian tradition-in the $70 \mathrm{~s}, 80 \mathrm{~s}$, and 90s - the collective and its psyche, including its deeply divisive social conflicts, were on the Jungian back burner, if they were on the stove at all. The collective 


\section{Singer}

psyche was something one individuated out of, even though lip service was paid to rejoining the community after an initiatory excursion into the more liminal aspects of psyche.

In reflecting on my interest in "cultural complexes," I have become more and more aware in the last decade that I was returning to my own early "roots" in Jungian psychology (Man and His Symbols, for instance) where the focus was as much on collective psyche as on the individuation process. I am continually surprised not only that there are different Jungs for different people, but also that there are different Jungs for the same person through various stages of development. In that regard, I have come to believe strongly, along with many other Jungians, post-Jungians, and perhaps even post-post Jungians, that individuation alone is not enough for a psychology that wants to speak fully to the multiple dimensions of human experience that Jung himself indicated in his 1926 diagram of the psyche (1989, pp. 41-42). It is clear from this image that Jung saw that "clans, nations, and large groups" constituted essential layers of the human psyche. It is not a big leap from this formulation to Henderson's notion of the cultural unconscious as a layer separate from both the personal and collective unconscious.

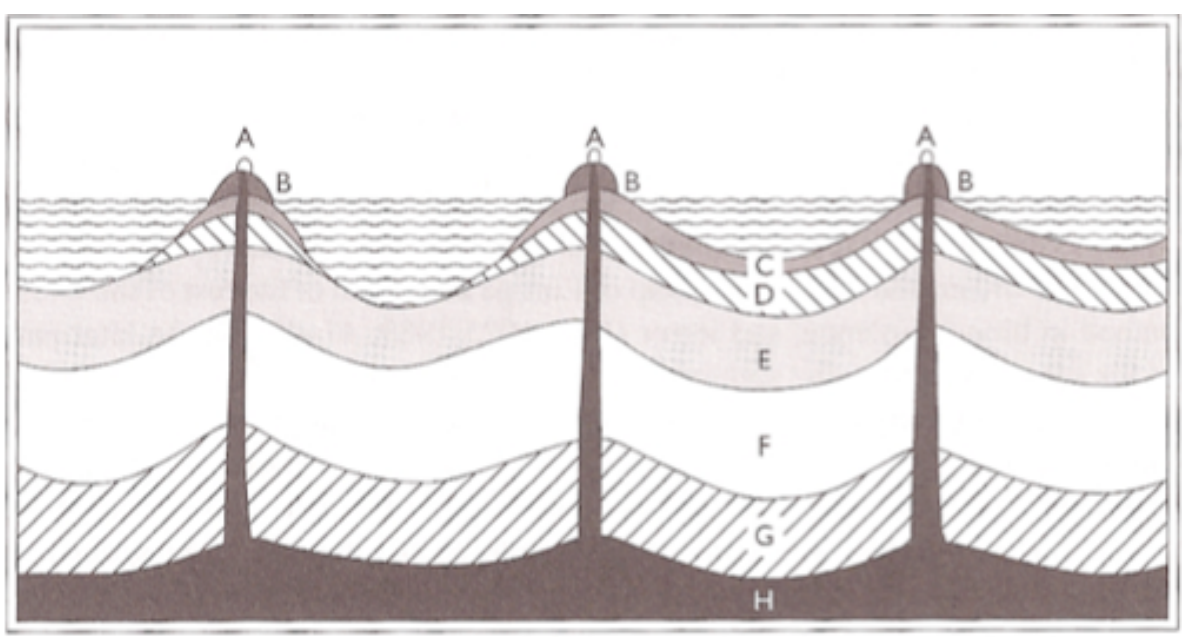

$$
\begin{aligned}
& A=\text { Individuals } \\
& B=\text { Families } \\
& C=\text { Clans } \\
& D=\text { Nations } \\
& E=\text { Large group (European man for example) } \\
& F=\text { Primate ancestors } \\
& G=\text { Animal ancestors in general } \\
& H=\text { "Central fire" }
\end{aligned}
$$




\section{Journal of Jungian Scholarly Studies 4}

By around 2000 my interests had gradually shifted back more to that part of the early Jung who was "taken" by the collective psyche. I became more involved in politics and more curious about the interface between psyche and society. However, I did not have a language and theoretical framework grounded in the Jungian tradition with which to fully express this interest and concern. I found the Jungian way of speaking of social and cultural phenomena-mostly in terms of archetypes - simplistic and reductionistic, although at times quite real and powerful. Over time I got tired of hearing about either the "hero" or the "shadow" as catch-all explanations for all sorts of collective experiences.

Appealing to the archetypes as explanatory principles simply did not get at or respect the uniqueness and specificity of individual cultures or how the archetypal level of the psyche came alive in unique ways in different places and times. I needed a real bridge between the archetypal and the specific, whether at the cultural/group level of experience or at the personal level of experience. I came to believe that one of the reasons Jung's essay "Wotan" (1936) - a favorite of minewas so readily interpreted as a pro-Nazi declaration was because Jung went too quickly to the archetypal level and did not offer his readers a sufficient bridge of specific cultural context - history, economics, politics - by which to understand the German possession by the northern god of "storm and frenzy" (para. 3).

\section{Complex Theory}

In The Vision Thing (2000), which I edited on the eve of the 2000 American presidential elections, I sought to connect psyche, myth, and politics. I was still lacking a specific vehicle, however, that more clearly and precisely connected personal and collective levels of psychic reality. I had long been steeped in Jung's complex theory as it applied to the individual. This "bread and butter" conceptual framework was the San Francisco Jung Institute equivalent to the model of defenses and wishes in the Freudian tradition. I learned to use complex theory in a clinical setting to formulate my understanding of intrapsychic and interpersonal conflicts. I can still remember a series of "ah ha" experiences when the complex theory "gelled" in my psyche and helped me make sense of very difficult psychological conflicts, both my own and my patients. In the 1970s, the theory, practice, and lived reality of complex psychology (a name that Jung considered giving to the school that grew up around him) came together for me in the same way that Jung's notion of the collective psyche helped awaken me to the nature of the powerful impact that the social and political revolution of the late 1960s had on the world. Most influential in my comprehension of the complex theory was John Weir Perry's seminal paper "Emotions and Object Relations" (1970), which was profoundly integrative in terms of Jungian complex theory, object relations theory, and Eriksonian developmental theory. 


\section{Singer}

Not every Jungian training center in the world has taken up complex theory with the same rigor and investment as the San Francisco Jung Institute where Perry, Wheelwright, Henderson, Sandner, and Beebe all elaborated on the theory and practice of using complex theory to understand ourselves and our patients. Some people and regions have been more receptive to the extension of complex theory to include cultural complexes because some Jungians already have integrated that theory into their everyday teaching and clinical practice. Other Jungian traditionsperhaps such as the JAP in England - just did not use and incorporate complex theory in the same way as San Francisco, so that its extension to group psychology seems as much of a stretch as using complex theory to understand individual psychodynamics.

Over the course of his life, Jung built a constantly evolving theoretical framework. Although his complex theory came before the "discovery" of archetypes, one can say, retrospectively, that Jung placed his notion of complexes between the personal and archetypal dimensions of the individual psyche. It became a Jungian "truism" that, at the heart of every complex, was an archetype. Put another way, the archetype often made its appearance in the individual psyche through its incarnation in the complex. In that sense, the complex is the mediator or bridge between the personal and archetypal in the individual. Jung, however, never extended that role of "mediator" or "bridge" to the complex when it came to what lay between a specific group and the archetypal or collective unconscious. Therefore, Jungians naturally went to archetypal explanations of group and cultural phenomena without a "bridge." Again, this, in my mind, contributed to the problem with "Wotan"- Jung (1936) offered no bridge that could link the specific psychic forces at work at the cultural or group level of the German psyche with the deeper archetypal layer of psychic energies in the collective unconscious, a bridge by which one could begin to understand the cultural ground in which the possession by Wotan would find such fertile soil.

This lack of a "bridge" raised important questions in my mind: How can the Jungian tradition, honoring its own fine history of thoughtful speculation about the nature of psyche, find a way to tap into its considerable body of knowledge and insight to speak about group and cultural phenomena that has one eye toward the specificity of unique groups in time, place, and history while, at the same time, have another eye focused on more archetypal themes that speak to universal human experience of living in groups and cultures? Do complexes exist in the group psyche that are akin to the personal complexes in the individual? By trying to tease out those cultural complexes can we gain a perspective on the intra- and intergroup conflicts that beset human beings in groups as diverse and often conflicted as blacks and whites, Islamic and Western citizens, men and women, aboriginal and colonial populations? 


\section{Journal of Jungian Scholarly Studies 6}

\section{Cultural Complexes}

My need to get a psychological perspective on old, even ancient, group conflicts that were essential components of my own personal development fueled these questions. For decades, I was troubled by the enduring conflicts between Jews and Christians that took up residence in my psyche, in my family, and in my community. This internal split was later joined by conflicts between the Freudian and Jungian groups who competed in me for a place of primacy. They lived in my psyche as if they were my own personal problems, much in the way that a child with divorced parents assumes that the parents' conflicts originated in a fault of the child. In this case, I was a child of a split between conflicted groups rather than divorced parents. As a well-assimilated Jew in a predominantly Christian culture and as a young Jungian in a family that had deep ties to the Freudian psychoanalytic tradition, I often felt as if I lived with the divisions between enemies that seemed to hate one another inside me. Hearing what the Freudians and Jungians had to say about one another was not that different from hearing what the Jews and Christians had to say about one another. Although the Freudians and Jungians did not literally slaughter one another, each group would have been happy if the other had not existed. Of course, Christians, Jews, Jungians, and Freudians were all often quite off-base in their understandings and criticisms of one another.

When I began to think of these toxic conflicts as being deeply entrenched group complexes that had taken up residence in my psyche in the same way that Jung defined personal complexes, I began to see some light between my personal psyche and the group psyches living within and around me (Singer, 2012). Sometimes I think that cultural or group complexes are a bit like splinter personalities of the collective psyche that walk around the streets like the zombies that inhabit so many current movies. However one imagines them, differentiating a personal level of complexes from a group level of complexes became an immensely liberating and deeply meaningful psychological task. I believe that the study and knowledge of cultural complexes can be as liberating and freeing to individuals (and sometimes even to groups) as can the working through of personal complexes.

We all learn from the difficult journey of struggling with our personal and cultural complexes. We discover that the stuff of a complex is sometimes as hideous as the teratomas that I first learned to identify in medical school. Teratomas are tumors consisting of different types of tissue such as skin, hair, teeth, fingernails, and muscle, which are caused by the development of highly organized and totally chaotic tissue. They grow randomly together in an ugly mass that is unforgettable. 


\section{Singer}

Analogous to a teratoma, a cultural complex has bits and pieces of thought, memory, affect, and behavior that glom together in a mass that defies rationality but very powerfully influences, even takes over, the more everyday "tissue" of social reality that surrounds it. Once one has experienced a cultural complex in one's self or someone close, its reality and its influence are undeniable. Toni Morrison, in Beloved (1987), articulates the voice of a cultural complex, a multigenerational voice of unparalleled, cumulative, and unending anguish of the black people. In its very inarticulateness, its "mumbling" communicates the most dreadful feelings and fixed beliefs that trade on fear, hatred, and distrust as its fundamental currency:

Stamp Paid ... believed the undecipherable language clamoring around the house was the mumbling of the black and angry dead. Very few had died in bed, like Baby Suggs, and none that he knew of, including Baby, had lived a livable life. Even the educated colored: the long-school people, the doctors, the teachers, the paper-writers and businessmen had a hard row to hoe. In addition to having to use their heads to get ahead, they had the weight of the whole race sitting there. You needed two heads for that. Whitepeople believed that whatever the manners, under every dark skin was a jungle. Swift unnavigable waters, swinging screaming baboons, sleeping snakes, red gums ready for their sweet white blood. In a way, he thought, they were right. The more coloredpeople spent their strength trying to convince them how gentle they were, how clever and loving, how human, the more they used themselves up to persuade whites of something Negroes believed could not be questioned, the deeper and more tangled the jungle grew inside. But it wasn't the jungle blacks brought with them to this place from the other (livable) place. It was the jungle whitefolks planted in them. And it grew. It spread. In, through and after life, it spread, until it invaded the whites who had made it. Touched them every one. Changed and altered them. Made them bloody, silly, worse than even they wanted to be, so scared were they of the jungle they had made. The screaming baboon lived under their own white skin; the red gums were their own. (Morrison, 2012, p. 234)

That is as good a description of how a cultural complex actually lives in the individual and collective psyche that I have come across. Not only is the suffering of the black people unfathomable but Morrison also notes its toxic effect on the white psyche as well: "The screaming baboon lived under their own white skin; the red gums were their own."

It is as if cultural complexes get started with a stem cell of an idea or belief or memory or traumatic event or powerful affect that over time grows into something 


\section{Journal of Jungian Scholarly Studies 8}

monstrous by accumulating all sorts of other things that are the psychic equivalent of randomly placed hair or teeth or fingernails. The persistent, ferocious attacks on Obamacare in the United States seem, to me, to be this kind of psychic, cultural complex teratoma. These masses of affect, memory, idea, belief, and behavior operate as independent, autonomous psychic beings in the body politic-much as Jung (1935/1976) originally described an individual complex:

The complex has a sort of body, a certain amount of it own physiology. It can upset the stomach. It upsets the breathing, it disturbs the heart - in short, it behaves like a partial personality. For instance, when you want to say or do something and unfortunately a complex interferes with this intention, then you say or do something different from what you intended. You are simply interrupted, and your best intention gets upset by the complex, exactly as if you had been interfered with by a human being or by circumstances from outside. (para. 72)

The meeting of psyche and society in the form of a cultural complex can be a terrifying phenomenon. At other times, a cultural complex can appear more well formed and rational, although often along the way it can take on a nonrational personality of its own that manages to get in the way of other social processes and interactions. For example, in the United States, cultural complexes around an unborn child's right to life versus a woman's right to choose, or gun control versus gun rights come to mind. One may argue that these are political conflicts rather than psychological issues, but in the collective psyche the intensity of emotion surrounding these "political" debates indicates that a cultural complex is deeply activated in these matters. Of course, there are other cultural complexes that are far more benign, even essential to the healthy identity of a group in the same way that Jung defined the ego-complex as a normal structure of the psyche. Therefore, one can think of cultural complexes as occurring along a spectrum, from more "normal" to more "pathological" in terms of their effect on society.

\section{Circumambulation and Recent Developments in the Study of Cultural Complexes}

The goal of the cultural complex studies I have participated in during the past decade has been to see if the notion has "legs" to stand on. Does it allow us to approach social and cultural conflicts around the world with respect for the uniqueness and specificity of time, place, and culture while, at the same time, noting psychological patterns that reflect a general way in which psyche structures itself in regard to collective or group situations? Does the notion provide a useful bridge between personal and collective, between conscious and unconscious, between individual and archetypal? Does the notion allow us to see a bit more 


\section{Singer}

clearly and even respond a bit more wisely to the inherently foggy borderlands between deeply conflicted groups - whether those conflicts are based on gender, ethnicity, race, politics, economics, cultural heritage, and all the other forces that divide people in groups from one another? Clearly, no one theory can provide all the answers to these type of questions. I do think a good enough theory, however, can allow one to walk around these problems in such a way as to honor their complexity and depth. Jungians like to call this type of approach "circumambulation" and the goal of the cultural complex researches has been to encourage a circumambulation of the collective psyche of different places, times, and cultures to see if it helps us understand a bit better the world of psyche. Please note that I place psyche at the center of the inquiry. Something as subtle as psyche will not be contained by a single concept or theory-including a psychological theory. Psyche is not history. Psyche is not economics. Psyche is not anthropology. Psyche is not sociology. Psyche is not even psychology. Rather psyche is embedded in all of these areas without being confined to any one of them. Thus, the methodology of exploring the collective psyche and its complexes needs to be truly a "walkabout" - both in terms of geography and in terms of symbolic content. With that in mind, to date, I have asked colleagues in Australia, Latin America, North America, the Middle East, and Europe to think about and explore cultural complexes and collective psyche in terms of their own specific culture, history, and conflicts. The results of these researches are available in several volumes (Placing Psyche: Cultural Complexes in Australia (2011), Listening to Latin America (2012), The Cultural Complex: Contemporary Jungian Perspectives on Psyche and Society (2004), European Cultural Complex (forthcoming), which I recommend to anyone interested in the topic as a way of seeing how our circumambulation has attempted to unite what is absolutely unique and specific in terms of time, place, culture, and geography to what is more universal in how the psyche of humankind structures itself with regard to the conflicts and shifting identities within individuals, the groups to which they belong, and the groups with which they find themselves at odds. I believe that the notion of cultural complexes contributes to an understanding of how the individual and collective psyche functions. I also believe that in time a neurobiological component will add another dimension to understanding cultural complexes by demonstrating in neurobiological research of the brain that historical memory of group experience will be shown to link with stereotypical ideation, primitive affect, potent imagery, and reflexive behavior-all of which are the characteristics of what are now called cultural complexes. Finally, I hope that these understandings will allow us to take more effective action in intervening in those more destructive cultural complexes that cause such havoc in society. 
Journal of Jungian Scholarly Studies 10

\section{Cultural Complexes and Effective Action}

The phrase "effective action" is a perfect segue to the final issue I want to address in this brief paper of personal reflections on the development of the cultural complex theory. For the past decade, I have not given a single presentation on the topic of cultural complexes in which the first or second question to me does not address the issue of how the theory might allow us to take more "effective action" in bringing about healing where a cultural complex has inflicted great damage on individuals and groups. Of what use is the theory if it does not suggest helpful, therapeutic interventions? Where is the healing? What is the cure? Almost before I have had a chance to describe the notion itself, people want to know how to fix it, how to do something about it. I have become resistant to the question over time, not because it is not absolutely relevant and needs to be addressed-but because many people do not actually seem to be willing or able to tolerate sitting with an exploratory question long enough to take in its dimensions and depth without immediately asking for an answer. Sometimes demanding an answer or a fix is a way out of tolerating the anxiety of not knowing the answer. The fact is that most often I do not have an answer to what will cure the toxic fog of a cultural complex. Craig san Roque (2012) of Australia writes beautifully about living in the fog of a cultural complex, where one can hardly formulate a question, much less provide an answer.

... I was preoccupied with the idea of how to detect a cultural complex when embedded in it, when asleep in it myself. Intrigued by the peculiar confusion of perception which grips the mind when under the influence of a complex, I kept thinking about the mythological Medusa gaze - where eyes cross and the brain turns to stone. The paralyzed sensation is, I feel, a symptom or sign of an active complex. Medusa is the patron saint of the complex. (p. 65)

As a society, we keep demanding answers for problems that seem to be quite adept at avoiding solutions. Failure to have an answer and refusing to give into the demand to provide one is no excuse, however, for not reflecting on possible meaningful responses to the intractable social problems that remain encrusted in cultural complexes. Therefore, I turn to history to look for examples of what I call cultural complexes to try to understand what interventions or other factors led to a shift in the collective psyche, resulting over time in some progress, some resolution, some healing. In a paper called "The Transcendent Function in Society" (2010), I cited three examples in which I thought long struggle had resulted in significant change in deeply entrenched cultural complexes. This has been true in gay rights over the past several decades, in women's rights over the past century, and even a bit in racial issues over the past 300 years. Enormous personal sacrifice 


\section{Singer}

and group struggle are often at the heart of a cultural complex finding some resolution. When public opinion that was in the long-term grip of a cultural complex shifts, it can feel somewhat miraculous, as if there was some tipping point in the cultural unconscious that finally released its tenacious hold on the collective psyche. A huge store of energy gets freed up for life instead of imprisonment. I think that this is how it has felt most recently to witness the profound shift in attitudes toward homosexuality and gay marriage.

In today's global climate of divisive and, at the same time, homogenizing (which can also be seen as the result of a cultural complex) forces, I believe that it is absolutely essential that we explore how the collective psyche functions if we are going to find any meaningful healing processes to the social, political, economic, and environmental problems that beset us. It is not enough, in my opinion, to "individuate"- that rarely attained Jungian state of wholeness that is often the stated goal of our work. As analytical psychologists, we need to reflect psychologically on the cultural complexes that besiege us and address them in way that both expresses our capacity to tolerate the ambiguity of seeing value on both or many sides of an issue and allows us to stand up as citizens for what we believe.

It is in the very nature of many of the cultural complexes that have us in their grips today (racism, sexism, ethnic warfare, homophobia, environmental conflicts) to generate profound splitting and polarization between groups. Both or all sides often have a firm belief in their view of "the truth" and that "human value" is on their side. It is harder for people caught in the grips of cultural complexes to see that they also may have "untruth" or "righteous dogma" on their side as well.

If you recognize a cultural complex at work and feel the urge to do something about it and you simultaneously recognize that both or all sides of a conflict are in the grips of a complex with each side having some claim of legitimate value, what

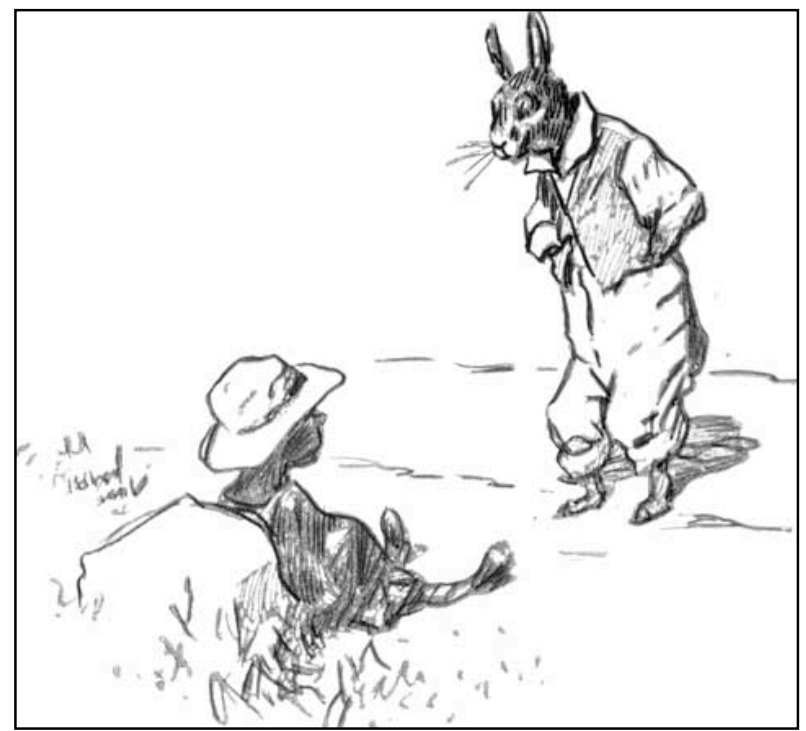

Image Caption: Brer Rabbit and the Tar-Baby from Uncle Remus. The Palestinian-Israeli struggle has educated more than one American President and English prime minister in how an international tar baby functions. (Retrieved from http://en.wikipedia.org/wiki/Br\%27er Rabbit\#mediaviewer /File:Br\%27er Rabbit and Tar-Baby.jpg). In the public domain. do you do? Do you sit on the sidelines and watch them fight it out-like in Syria or Israel? Do you wait for the "transcendent function" to make a mysterious appearance and bring on the "third" or "fourth"? Do you try to introduce some insight about the underlying psychology of the situation, which more often than not falls on deaf ears? The collective psyche can be a 


\section{Journal of Jungian Scholarly Studies 12}

beast. Its cultural complexes often function like "tar babies"- the more you try to get involved to sort things out, the more you get stuck in the problem (Tar-Baby, 2014).

I do believe that when we recognize a cultural complex at work on an important social issue, we are obliged to take a stand and do our best not to contribute more to the splitting and polarization that seem inevitably to accompany such conflicts. The analytical psychologist part of us will want to be as objective as possible about the nature of the conflict between groups so we can see the human value that is being affirmed on all sides of a conflict. The citizen part of us needs to take a stand, often with one side or the other-because it is the nature of these kinds of conflicts that the polarization and splitting in the collective psyche requires one to choose one side or the other. As psychologists, we want to see the value and problem from both sides or multiple sides; as citizens, we often have to choose one among many possible sides.

\section{References}

Amezaga, A., Barcellos, G., Capriles, Á., Gerson, J., \& Ramos, D. (Eds.) (2012). Listening to Latin America: Exploring cultural complexes in Brazil, Chile, Colombia, Mexico, Uruguay, and Venezuela. New Orleans: Spring.

Jung, C. G. (1935/1976). The Tavistock lectures. In The symbolic life (Vol. 18). Princeton: Princeton University Press.

Jung, C. G. (1936). From “Wotan” by Carl Jung. In Madness and civilization: An anthology. Retrieved from http://ahistoryofthepresentananthology.blogspot.com/2013/03/wotanby-carl-jung-1934.html.

Jung, C. G. (1963). Memories, dreams, reflections. Edited and recorded by A. Jaffé. R. Winston and C. Winston (Trans.). New York: Random House.

Jung C. G. (1989). Analytical psychology: Notes on the seminar given in 1925. W. McGuire (Ed.) Princeton: Princeton University Press.

Morrison, T. (1987). Beloved. New York: Random House.

Perry, J. W. (1970). Emotions and object relations. Journal of Analytical Psychology, 15, 1-12.

San Roque, C. (2011). The lemon tree. In Placing psyche: Cultural complexes in Australia. New Orleans: Spring.

San Roque, C., Dowd, A., \& Tacey, D. (Eds.). 2011. Placing psyche: Cultural complexes in Australia. New Orleans: Spring.

Singer, T. (Ed.). (2000). The vision thing. Myth, politics, and psyche in the world. London: Routledge.

Singer, T. (2010). The transcendent function in society. Journal of Analytical Psychology, 55, pp. $229-254$

Singer, T. (2012). The meshugana complex: Notes from a big galoot. Jung Journal: Culture \& Psyche, 6(1), pp. 72-84.

Singer, T., \& Kimbles, S. (Eds.). (2004). The cultural complex: Contemporary Jungian perspectives on psyche and society. London: Routledge.

Tar-Baby. (2014, May 23). Wikipedia. Retrieved from http://en.wikipedia.org/wiki/Tar-Baby.

Wiener, E. (2012, March 9). Where heaven and earth come closer. New York Times. Retrieved from http://www.nytimes.com/2012/03/11/travel/thin-places-where-we-are-jolted-outof-old-ways-of-seeing-the-world.html? $\mathrm{r}=0$. 


\section{Thomas Singer, Books and Articles Related to the Cultural Complex}

\section{Books}

1. The vision thing: Myth, politics, and psyche in the world. London: Routledge, 2000.

2. The cultural complex: Contemporary Jungian perspectives on psyche and society. London: Routledge, 2004.

3. Initiation: The living reality of an archetype. London: Routledge, 2007.

4. Psyche and the City: A soul's guide to the modern metropolis. New Orleans: Spring, 2010.

5. Placing psyche: Cultural complexes in Australia. New Orleans: Spring, 2011.

6. Listening to Latin America: Exploring cultural complexes in Brazil, Chile, Colombia, Mexico, Uruguay, and Venezuela. New Orleans: Spring, 2012.

7. European Cultural Complexes. New Orleans: Spring, in preparation.

\section{Articles and Chapters}

1. Singer, T. (2002). The cultural complex and archetypal defenses of the collective spirit: Baby Zeus, Elian Gonzales, Constantine's Sword, and other Holy Wars. The San Francisco Library Journal, 20(4), pp. 4-28.

2. Singer, T. (2003). Cultural complexes and archetypal defenses of the group spirit. In J. Beebe (ed.), Terror, Violence and the Impulse to Destroy (pp. 191-209). Zurich: Daimon Verlag.

3. Singer, T. (2006). Unconscious forces shaping international conflicts: Archetypal defense of the group spirit from Revolutionary America to conflict in the Middle East. The San Francisco Jung Institute Library Journal, 25 (4), pp. 6-28.

4. Singer, T. (2006). The Cultural Complex: A Statement of the Theory and Its Application. In Psychotherapy and Politics International. Hoboken, NJ: Wiley.

5. Singer, T. (2007a). In the footsteps: The story of an initiatory drawing by Dr. Joseph Henderson. In T Kirsch, V. Rutter, and T. Singer (Eds.), Initiation: The living reality of an archetype. London: Routledge.

6. Singer, T. (2007b). A personal meditation on politics and the American soul. Spring Journal, 78, pp. 121-147.

7. Singer, T. (2007c). ARAS: Archetypal symbolism and images. Visual Resources, Vol. XXIII, No. 3, September, pp. 245-267.

8. Singer, T. (2009a). A Jungian approach to “us vs. them” dynamics. Psychoanalysis. Culture and Society, 14(1), pp. 32-40.

9. Singer, T., with Kaplinsky, C. (2009b). The cultural complex. In M. Stein (Ed.) Jungian Psychoanalysis. Chicago: Open Court.

10. Singer, T. (2010a). Playing the race card. In G. Heuer (Ed.), Sacral revolutions: Reflecting on the work of Andrew Samuels. London: Routledge.

11. Singer, T. (2010b). The transcendent function in society. Journal of Analytical Psychology, 55, 229-254.

12. Singer, T. (2010c). Afterword: St Louis. In T. Singer, Psyche and the city (pp. 403-411). New Orleans: Spring, pp. 403-411.

13. Singer, T. (2012). The meshugana complex: Notes from a big galoot. Jung Journal: Culture \& Psyche, 6(1), pp. 72-84. 
14. Singer, T. (2013). Amplification: A personal narrative. In E. Shalit and N. Furlotti (Eds.), The Dream and its amplification. Skiatook, OK: Fisher King Press. 